\title{
Eğitim Amaçlı Oyunlarda İş Modeli Seçeneklerinin Belirlenmesi*
}

\section{Determining Business Model Options in Serious Games}

\author{
Doç. Dr. Mustafa Halid KARAARSLAN ${ }^{(D)} 1$
}

\begin{abstract}
$\ddot{O} z$
Tüm toplumlar için en önemli sorunlardan biri nitelikli insan yetiştirebilmektir. Bu sebeple dünyada eğitimin niteliğini ve öğrencilerin derse olan ilgisini artırmaya çalışılmaktadır. Oyunlaştırma teknikleriyle (çoğunlukla teknoloji kullanılarak) öğrenmenin etkinliğinin artırılabileceğine yönelik değerlendirmeler yapılmaktadır. Oyunlaştırmayla eğitim daha eğlenceli ve katılımcı hale getirilebilmektedir. Oyunlaştırmanın bir alt dalı ise eğitim amaçlı oyunlardır (serious games). Eğitim amaçlı oyunlar okul öncesi eğitimden üniversite eğitimine, toplumu bilinçlendirme çalışmalarından mesleki eğitimlere kadar her düzeydeki eğitimde kullanılma kapasitesine sahiptir. Bu makalenin konusu eğitim amaçlı oyunların iş modellerinin neler olduğunun tespit edilmesidir. Eğitim amaçlı oyunların iş modelleri hedef kitle (oyun kimin için geliştirilecek?), değer önerisi (hedef kitle neden bizi tercih edecek?), dağıtım kanalı (hedef kitleye nasıl ulaşılacak?) ve gelir modeli (masrafları karşılayacak gelir nasıl elde edilecek?) incelenmiştir. Sonuç olarak eğitim amaçlı oyunlar tasarlanırken hedef kitlenin incelenerek değer önerisinin müş̧erilerin satın alma tercihlerine göre belirlenmesi gerektiği, gelir modeli belirlenirken sadece müşterilerden elde edilecek gelirin değil aynı zamanda eğitime katkı sunacak sponsorların ve hedef kitleye ulaşmak isteyen reklam verenlerin de göz önüne alınması gerektiği tespit edilmiştir.
\end{abstract}

Anahtar Kelimeler: Eğitim amaçlı oyunlar, oyunlaştırma, iş modeli, gelir modeli, değer önerisi

Makale Türü: Derleme

\begin{abstract}
One of the most important problems for all societies is to raise more qualified people. For this reason, efforts are being made to increase the quality of education in the world and to increase the interest of students on the course. With the help of the techniques of gamification (mostly using technology), the effectiveness of learning can be increased. Gamification can make education more fun and participatory. Serious games (educational games) are a subdivision of gamification. Serious games have the capacity to be used at all levels of education, from preschool education to university education, community awareness studies to vocational training. The subject of this article is to determine the business models of serious games. When the business models of serious games are discussed, the target group (what was the game developed for?), the value proposition (why the target group would prefer?), the distribution channel (how to reach the target group?) and the revenue model (how to earn revenues to cover costs?). As a result, it was determined that while designing serious games, the target audience should be examined and the value proposition should be determined according to the purchasing preferences of the customers, while determining the revenue model, not only the income to be obtained from the customers, but also the sponsors who will contribute to education and the advertisers who want to reach the target audience should be taken into account.
\end{abstract}

Keywords: Serious games, gamification, business model, revenue stream, value proposition

Paper Type: Review

\footnotetext{
*Bu çalışmanın ilk hali 19-22.09.2018 tarihinde Budapeşte'de düzenlenen Third Mediterranean International Congress on Social Sciences (MECAS III) kongresinde Bildiri Özet Kitabında yayınlanmıştır.

${ }^{1}$ Karabük Üniversitesi, İşletme Fakültesi, mustafahk@karabuk.edu.tr.
}

Atıf için (to cite): Karaarslan, M. H. (2020). Eğitim amaçlı oyunlarda iş modeli seçeneklerinin belirlenmesi. Afyon Kocatepe Üniversitesi Sosyal Bilimler Dergisi, 22(4), 935-947. 


\section{Giriş}

Teknolojik cihazlar icat edildiklerinde bunların eğitim alanında önemli dönüşümler sağlayabileceği üzerine oldukça iyimser yorumlar yapılmıştır. Örneğin Edison fonografı icat ettiğinde eğitimle ilgili işlerde kullanılabileceğini öngördü. Ancak cihaz en çok müzik için kullanıld1 (Basalla, 1996, s. 188-9). Benzer bir durum kaset, radyo ve televizyonun yaygınlaşması sürecinde de yaşandı. Bunların etkin olarak eğitimde kullanılması beklenirken bu araçlar da çoğunlukla eğlence için kullanıldı. Türkiye'de televizyonun bir eğitim aracı olarak kullanılması yönünde her ne kadar çabalar olsa da (Yapıc1, 2006), arzu edilen sonuçlar alınamadı. Millî Eğitim Bakanlığı tarafından 2010 yılında uygulanmaya alınan Fırsatları Artırma ve Teknolojiyi İyileştirme Hareketi (FATİH) ile örgün eğitimde teknoloji kullanımı yaygınlaştırılmaya çalışıldı. Ancak projeye, öğrencilerde dikkat dağınıklığını artırdığı ve öğrencileri pasifleştirdiğine yönelik eleştiriler bulunmaktadır (Çelik, Karakuş, Kurşun, Göktaş ve Özben, 2017, s. 68). Kore ve Türkiye'deki eğitimde teknoloji uygulamalarını karşılaştıran bir çalışmada Türkiye'de sorunun düşük teknoloji kullanımı olmadığı daha çok uygulamada yapılan hatalar ve merkeziyetçi yaklaşım olduğu sonucuna ulaşıldı (Başak ve Ayvacı, 2017, s. 482-484). Bu yönüyle değerlendirildiğinde teknolojik cihazların eğitimde kullanılmasının yeterli olmadığı sonucuna ulaşabilmek mümkündür.

Eğitimin geleneksel yapıdan uzaklaştırılması için geliştirilen önerilerde "oyun” önemli bir kavram halini almaktadır ve sadece teknolojik cihazlarla sınırlı değildir. Oyun, canlıların öğrenmesine yardımcı olan ve bunun yanında eğlendiren önemli bir etkinliktir. Bilindiği üzere canlıların hayatlarındaki ilk evrelerinde genellikle öğrenme ve eğlence birlikte devam etmektedir (Altuntaş ve Karaarslan, 2017, s. 279). İnsanların herhangi bir konuya ilgisini çekmek, katılımını sağlamak ve faaliyeti sürdürme motivasyonunu arttırmak için her alanda oyunlardan yararlanılması gerektiği fikri her ne kadar uzun zamandır üzerinde konuşuluyor olsa da özellikle 2000'li yıllarla birlikte oyunlaştırma kavram olarak kullanılmaya başlanmıştır (Altuntaş ve Karaarslan, 2016, s. 434). Oyunlaştırma mevcutta var olan herhangi bir eğitim aracını, çevrimiçi topluluğu ya da diğer girişim sistemlerini alarak, katılımı sağlamak, motivasyonu ve bağlılığı arttırmak gibi amaçları gerçekleştirmek için bu araçlara oyun mekaniklerinin entegre edilmesidir (Bunchball, 2016). Buradan anlaşılacağı üzere oyunlaştırma eğitim ve diğer aktivitelere katılımı ve motivasyonu artırmak için oyunun kullanılmasıdır. Oyunlaştırma eğitimi de kapsayan geniş bir konu olduğu için çalışma kapsamında kullanılacak terim eğitim amaçlı oyunlar (serious games, game-based learning) olacaktır. Eğitimde oyunlaştırma öğrenmeyi daha eğlenceli hale getirerek daha kolay öğretme potansiyelinden yararlanmak için yapılır (Karataş, 2014, s. 318).

2020 yılında ortaya çıkan salgın dolayısıyla yüz yüze eğitim ciddi oranda sekteye uğramış ve tüm eğitim kurumlarının uzaktan eğitime geçmeleri gerekmiştir. Bu durum eğitimdeki dönüşümleri hızlandırmıştır. Daha önce denenerek vazgeçilen televizyondan eğitime tüm ilk ve orta eğitim kurumlarında geçilmiştir. Aynı zamanda çevrim içi eğitimlere ilk ve orta dereceli okullarla beraber yüksek öğretimde de başlanılmıştır.

Yeni dönemde eğitim amaçlı oyunlar daha önemli hale gelmiş̧ir. Eğitim alan kişilerin konuyu kavramaları ve pratik yapmaları eğitim amaçlı oyunlar sayesinde mümkün olabilecektir. $\mathrm{Bu}$ oyunların kişinin kendi başına veya bir grupla oynayabilmesi, hızlı geribildirim verebilmeleri, raporlama özellikleri ve gerçek durumu benzetim (simulation) edebilmeleri eğitim içerisinde daha fazla kullanılmalarını sağlamaktadır.

$\mathrm{Bu}$ çalışmanın konusu eğitim amaçlı oyunların iş modellerinin belirlenmesidir. İş modelleri bir fikrin hayata geçirilmesindeki yöntemdir. Eğitim amaçlı oyunlar eğitim alanlar için uygun ve oyun mekanikleri açısından doğru kurgulanmış olsalar bile iyi bir iş modeline sahip değillerse başarısızlıkla yüzleşmektedirler. Bu çalışma eğitim amaçlı oyun tasarlayan eğitimcilerin ve yazılımcıların hangi iş modeli seçeneklerine sahip olduklarını açıklamaktadır ve onlara doğru bir iş modeli tasarlama konusunda yardımcı olmayı amaçlamaktadır. 
Çalışmada oyun geliştirmenin teknik veya pedagojik kısımlarına değinilmeyecektir. Sadece konuya işletmecilik bakış açısıyla bakılarak iş modellerinin nasıl geliştirilebileceğine odaklanılacaktır. Bu bağlamda çalışmada hedef kitle, değer önerisi, dağıtım kanalları ve gelir modelleri ile ilgili bilgi verilmektedir. Sonuç bölümünde ise eğitim amaçlı oyun geliştiricilerine ve eğitim kurumlarına öneriler yer almaktadır.

\section{Eğitim Amaçlı Oyunlar}

Eğitim amaçlı oyunlar öğrencilerin eğitim etkinliklerine aktif katılmalarını ve zevk alarak öğrenmelerini amaçlamaktadır. Burada oyun araçtır ve oynarken öğrenmeye değil, öğrenirken oynamaya ağırlık verilmektedir (Güneş, 2015, s. 777-778). Eğitim amaçlı oyun geliştiricileri için, eğlencenin seviyesini oyunun eğitimsel amacı ile dengelemek bir zorluktur (Laamarti, Eid ve Saddik, 2014, s. 12). Eğitim amaçlı oyunlar tasarlanırken dikkat edilmesi gereken aşamalar bulunmaktadır. Bu aşamalar Werbach ve Hunter (2012, s. 85-86) tarafından şu şekilde belirtilmiştir: iş süreçlerinin tanımlanması, hedef davranışların betimlenmesi, oyuncuların tanımlanması, aktivite döngülerinin tasarlanması, eğlencenin tasarlanması ve uygulama haline getirilmesidir.

Belirlenen bu aşamalarla birlikte bir diğer önemli husus da oyunculara (katılımcılara) oyun içerisinde birtakım değerlerin sunulmasıdır. Bu değerler sunularak oyun daha fazla zevk verir, ögrenmeye daha fazla güdüler. Böylece oyun geliştirilme amacına daha fazla hizmet eder. Bu bağlamda 6 değer önerisi belirlenmiştir (Cagnina ve Poian, 2009, s: 63-65):

Başarı (Achivement): Kullanıcının oyunda yapmaya çalıştığı veya yapmak zorunda olduğu hedefler.

Kontrol (Control): Kullanıcıların davranışlarının kontrol edilmesi ve gözlemlenmesini ifade eder.

Yaratıcılık (Creativity): Kullanıcının kendi içeriğini geliştirebilmesi ve kullanabilmesini ifade eder.

Sosyalleşme (Sociality): Kullanıcıların birbirleri ile iletişim kurabilmelerini ifade eder.

Gerçekçilik (Realism): Her sanal dünya bir fantezi ortamı oluşturur, onun için grafikleri ve kurgusunun oluşturulmak istenen fantezi ile tutarlı olması gerekir.

Üyelik (Membership): Bir topluluğun üyesi olmayı ifade eder. Kişilerin birbirleri ile kurdukları yakın iş birliği sadık bir üye olmada önemlidir.

Eğitim amaçlı tasarlanan ve kullanıcıların beğenisine sunulan oyunlar ve pazar büyüklükleri her geçen gün artmaya devam etmektedir. Dünya çapında 2017 yılında 3,2 milyar ABD Doları olan eğitim amaçlı oyunun pazarının 2022 yılında 8,1 milyar ABD doları olması beklenmektedir (Adkins, 2017, s. 7). Tüm kıtalarda eğitim amaçlı oyunlar ciddi potansiyel taşımaktadır. 2022'ye kadar en hızlı büyüyecek pazarların ise Afrika, Doğu Avrupa ve Latin Amerika pazarları olması beklenmektedir (Adkins, 2017, s. 8).

Eğitim alanında oyunlaştırmanın etkisi üzerine yapılan araştırmalar bulunmaktadır. Oyunlaştırmanın akademik başarı üzerine etkisinin incelendiği araştırmalarda (Karataş, 2014, s. 315) oyunlaştırma uygulamalarının öğrencinin derse katılımını artırdığı (Patterson, Kilpatrick ve Woebkenberg, 2010, s. 606), öğrencilerin hatırlamalarını kolaylaştırdığı (Bolat, Şimşek ve Ülker, 2017, s. 1753) ve oyunun akışına kapılan öğrencilerde oyun başarısını arttırdığ (Admiraal, Huizenga, Akkerman ve Ten Dam, 2011, s. 1192) bulunmuştur. Eğitim amaçlı oyunların geleneksel eğitimlere göre etkilerinin meta-analiz yöntemiyle inceleyen farklı bir çalışmada eğitim amaçlı oyunlarda öğrenme ve öğrenilenin kalıcılığı fazla olurken, motivasyon konusunda ise daha iyi olmadığ bulunmuştur (Wouters, Van Nimwegen, Van Oostendorp ve Van Der Spek, 2013, s. 249). Bununla birlikte eğitim amaçlı oyunlar ile geleneksel öğrenme arasında ders başarısı ve öğrenme çıktıları açısından anlamlı farklılık bulamayan çalışmalar da 
söz konusudur (Lasry, 2008, s. 4; Admiraal vd., 2011, s. 1192; Bolat vd., 2017, s. 1753; Patterson vd., 2010, s. 606).

İş modeli girişimcilik araştırmalarının merkezindeki yapı olarak kabul edilebilir (Morris, Schindehutte ve Allen, 2005, s. 734). İş modeli girişimin nasıl işlediğini açıklar (Magretta, 2002, s. 4) ve teknik potansiyel ile ekonomik değeri birbirine bağlayan sezgisel mantıktır (Chesbrough ve Rosenbloom, 2002, s. 529). Bir girişim ortaya çıkmadan önce, iş modeline karar vermek durumundadır. İyi bir iş modeli Peter Drucker'ın "Müşteri kimdir ve müşteri değeri nedir?" ve "Bu işten nasıl para kazanacağız?" sorularına cevap verebilmelidir (Magretta, 2002, s. 4). İş modeli her sektöre göre farklilaşabilmekle beraber belirli stratejik seçimler şeklinde ifade edilebilir (Barneto ve Ouvrard, 2015, s. 126). İş modeli ile ilgili başlıca kavramlar; sürdürülebilirlik, gelir akışı, maliyet yapısı, değer zinciri, değer önerisi, hedef kitle, paydaşların ağı, dağıtım kanalı, gelir akışı, ürün ve hizmet üretimi ve değişimidir (Zott, Amitt ve Massa 2011, s. 1028). 1960'lı yıllarda iş modeli ile ilgili ilk çalışmalar başlamıştır (Barneto ve Ouvrard, 2015, s. 126). Ancak 1995 'ten sonra iş modelleri üzerine yapılan çalışmalar yoğunluk kazanmıştır (Zott vd., 2011, s. 1023). İş modelleri üzerine çalışmaların artmasındaki sebepler işletmeye bütüncül bakış açısının gerekliliği ve yeni iş modelleri ile ortaya çıkan işletmelerin hızla sektörü dönüştürmeleri, internet girişimlerinin ortaya çıkması ile yeni iş modellerine olan ihtiyaç olarak sayılabilir.

\section{Yöntem}

İş modelleri girişimcilik literatüründe sıklıkla açıklanan unsurlar arasındadır. Peter Drucker iş modelini hedef kitle, değer önerisi ve gelir akışını içerecek şekilde tanımlamıştır (Magretta, 2002, s. 4). Osterwalder ve Pigneur (2016) ise iş modelini 9 unsuru içerecek şekilde genişletmişlerdir. Pazar bölümleri, değer önerisi, kanallar, gelir akışı, müşteri ilişkileri, temel faaliyetler, temel kaynaklar, temel ortaklıklar ve maliyet yapısını içermektedir. Bu çalışma kapsamında iki iş modeli yaklaşımının da içeriğinde bulunan hedef kitle (ilgili bölümde açılanacağı üzere ilk olarak pazarın bölümlenme gerekip gerekmediği tespit edilir sonrasında hizmet sunulacak hedef kitle tespit edilir), değer önerisi ve gelir modeli açıklanmıştır. Ayrıca Osterwalder ve Pigneur (2016) iş modelinden kanallar eklenerek toplamda 4 iş modeli unsuruna göre eğitim amaçlı oyunlar incelenmiştir.

\subsection{Hedef Kitle}

Bir eğitim amaçlı oyun hazırlanmaya başlamadan önce hedef kitle tespiti yapılmaktadır. Hedef pazar, pazarlamacı veya perakendeci tarafından ürünlerini veya hizmetlerini satın alma olasılığı en yüksek olan (yani hedeflenen) toplam nüfusun belirli bir kısmıdır (AMA, 2020). Buradaki temel amaç oyunun kimin için tasarlanacağının tanımlanmasıdır. Tüm müşteriler ve potansiyel müş̧erilerin altkümesinden oluşan hedef kitle seçilirken pazarın çeşitli özelliklerine göre bölümlendirilmesi gerekebilir. Bölümlendirmede ilk olarak kullanıcıların yaş, cinsiyet, gelir ve eğitim gibi demografik özelliklere göre farklı bölümlere ayırmanın anlamlı olup olmadığının kontrol edilmesinde fayda görülmektedir. Bilindiği üzere demografik özelliklere göre pazarı bölümlendirmek hem kolay hem de ikincil veri bulma şansı oldukça yüksektir. $\mathrm{Bu}$ sebeple demografik pazar bölümüne dayanan hedef kitle seçimine sık rastlanılmaktadır. 20-25 yaş arası üniversite eğitimine devam eden veya yeni mezun kişiler gibi pazar sadece tek bir kritere göre değil aynı zamanda birden çok kritere göre bölümlendirilebilir. İkinci olarak coğrafi olarak pazar bölümlendirmesi yapılabilir. Hangi büyüklükteki yerleşim yerinde yaşadığı, iklim özellikleri vb. gibi kriterlere göre pazar bölümlendirilebilir. Üçüncü olarak kişiler psikografik özelliklerine göre farklı pazar dilimlerinde yer alabilirler. Yaşam tarzı, değerleri, kişilik özellikleri bölümlendirirken dikkate alınan etmenlerdir. Dördüncü olarak ise davranışsal özellikler yönünden bölümlendirmenin yapılmasıdır. Bu durumda kişiler eğitim amaçlı oyunu hangi motivasyonla ve hangi yarar beklentisiyle oynadıkları, ne kadar süre ile oynadıkları, nereden ve hangi sıklıkla satın aldıkları, ödemeyi nasıl yaptıklarına göre sinıflandırılmaktadırlar. 
Pazar bölümlendirme stratejisi, bir pazarı bölümlere ayırdıktan sonra, hangi pazar bölümlerine hizmet vermenin kârlı olduğunu belirlemektir (AMA, 2020). Pazar bir ya da birkaç kritere göre bölümlendirilmesinin ardından bu pazar bölümlerinden hangisinin seçileceğine karar verilmektedir. Bir pazar bölümünü seçmek diğer tüm pazar bölümlerinden vazgeçmek anlamına geleceğinden, seçilecek pazar bölümünde eğitim amaçlı oyunu geliştirenin amaçlarını karşılayabiliyor olması arzu edilir.

Hedef kitle anlaşı1madan yapılacak tüm faaliyetlerin başarısızlık riski yüksek olacaktır. $\mathrm{Bu}$ sebeple oyun geliştiricilerinin hedef kitle analizini öncelikli olarak yapmaları uygun olacaktır.

\subsection{Değer Önerisi}

Müşteri değer önerisi, bir müşterinin satın alması ve ilgili ödeme (veya diğer değer transferi) karşılığında alacağına söz verilen faydaların toplamıdır (AMA, 2020). Değer önerisi ile "hedef kitle neden başkasını değil de bizim ürünümüzü tercih etsin?" sorusuna cevap verilmeye çalışılır. Geliştirici tasarlayacağı eğitim amaçlı oyunla ilgili olarak bu soruya çok faklı cevaplar vermesi olasıdır. Ancak verilen cevapların iyi bir değer önerisine dönüşmesi için bazı şartları sağlaması gerekir. İşletmenin rakipten üstün olduğu alanların sayısı çok olsa bile müşterinin tercihini belirleyen en önemli özellikler ön plana çıkarılır. Müşterilerin satın alma kararını etkileme gücü olmayan bir hususun değer önerisi olarak sunulması anlamlı olmayacaktır. Değer önerisinin rakipler tarafından sahiplenilmemiş olması gerekir. Zira aynı değer önerisine sahip olmak rekabetin daha zorlu olmasına yol açacaktır. Geliştiricinin vaadinin rasyonel olması halinde ispatlanabilmesi gerekir. Örneğin “...oyunu öğrenmeyi kolaylaştırır” şeklinde bir önermesi var ise bununla ilgili bir araştırma sonucunu paylaşabilmeli ya da gerçekten öğrenmeyi kolaylaştırdığına dair somut birtakım deliller ortaya koyabilmesi gerekir. Bununla birlikte rakiplerinden daha iyi olduğu bir alanda, rakiplerinin kolayca taklit edemeyeceği bir değer önerisinde bulunulmalıdır. Bir değer önerisi sahiplenildiğinde değiştirmek oldukça zor ve maliyetli olacağından geliştiriciye uzun vadede rekabet üstünlüğü sağlayan bir değer önerisi olmasına özen gösterilmelidir.

\subsection{Dağıtım Kanalı}

Dağıtım kanalı pazarlama görevini gerçekleştirmek için üreticileri son müşterilere ulaştırmak için gerekli tüm işlevleri bir arada yerine getiren organize bir ajans ve kurum (sistemidir) ağıdır (AMA, 2020). İşletme, hedef kitlesinin özelliklerine göre hangi cihazlarda ve platformlarda oyun üreteceğine karar verdikten sonra dağıtım kanalına karar verecektir. Oyunlar için farklı dağıtım kanalları mevcuttur. En eski dağıtım kanalı fiziksel mağazalardır. Genellikle kişisel bilgisayarlar ve oyun konsolları için üretilmiş oyunlar çeşitli teknoloji mağazaları ve kitap zincirlerinde satılabilmektedir. İkinci dağıtım kanalı ise oyun geliştiricisinin ya da onun anlaşmalı olduğu dağıtım şirketinin internet sitesinden satış yapılmasıdır. Üçüncü olarak internet üzerinden satış yapan perakendeciler aracılığıyla satışın gerçekleştirilmesidir. Dördüncü olarak ise son yıllarda en yaygın dağıtım kanalı olan platform mağazalarının kullanılmasıdır. Son yıllarda akıllı telefon işletim sistemi üreticileri, oyun konsolu üreticileri ve kişisel bilgisayar işletim sistemi üreticilerinin tamamı oyunların satın alınabildiği merkezi platform mağazaları oluşturdular. Böylece işletmeler geliştirdikleri oyunları bu platformlara yükleyerek satışlarını gerçekleştirebildiler. Beşinci ve son yöntem ise devletle bağlantılıdır. Devletlerin dijital öğrenme platformları aracılığıyla satış yapılabilmektedir. Ancak burada kullanıcılar kurum çalışanları veya öğrenciler olurken, ödemeyi devletin kendisinin yapmasından dolayı bu kanala giriş diğerlerine göre zor olmaktadır.

\subsection{Gelir Modeli}

Eğitim amaçlı oyun geliştiricileri katlandıkları masrafları karşılayabilmek ve sürekliliği sağlayabilmek için gelire ihtiyaç duyarlar. Gelir modeli belirli bir kaynaktan (her bir pazar bölümünden) bir işletmeye veya kuruluşa gelen bir miktar para (Collinsdictionary, 2020) 
anlamına gelir. Geliştiriciler için gelir modelleri sırasıyla oyun satışından elde edilen gelir, temel özellikler ücretsiz iş modeli, kitle fonlaması ve bağıştır. Geliştiriciler hedef kitlelerinin özelliklerine, hazırladıkları oyunun türüne ve dağıtım kanallarının yapısına göre geliştirdikleri farklı oyunlar için farklı gelir modellerini tercih etmektedirler. Aynı oyun için farklı zamanlarda farklı gelir modelleri mümkün olabildiği gibi aynı oyun için eş zamanlı olarak farklı gelir modellerini uygulanabilmektedir.

\subsection{1. Ücretli Gelir Modeli}

İşletme geliştirdiği oyun için belirli bir bedel ister. Bu bedeli ödemeden ilgili oyunun oynanması olanaksızdır. Eğitim amaçlı oyunlarda ise kişinin satın aldığı modüllere göre ücretlendirme yapılabilmektedir. Verilen ücretle oyunun sahipliği kişiye geçebildiği gibi belirli süre sonunda oyunun kullanım hakkı sona erebilmektedir. Genellikle fiziksel olarak satılan ve cihaza yüklenen oyunlarda ücret kullanım öncesinde tek seferlik ödenmektedir. İnternet üzerinden oynanan oyunlarda ise oyunun ücreti oynanacak süreye ve modüllere göre tespit edilmektedir.

\subsubsection{Temel Özellikler Ücretsiz Gelir Modeli}

Eğitim amaçlı oyunlarda en sık karşılaşılan gelir modeli temel özelliklerin bedava (freemium) olmasıdır. Kullanıcılar temel özellikleri kullanabilmek için herhangi bir ücret ödemesi gerekmemektedir. Ancak ek özellikler ücretlidir, ne var ki ücretli versiyonu kullananlar toplam kullanıcıların \%7-9'nu oluşturmakta geriye kalan büyük kısım ise ödeme yapmamaktadır (Georgieva, Arnab, Romero ve de Freitas, 2015, s. 36). Türkiye'de ücretli versiyonu kullanma oranları daha da azdır. $\mathrm{Bu}$ iş modelinde oyun geliştiricileri masraflarını karşılamak veya kâr elde edebilmek için kullanıcılar, kamu kurumları, iş verenler, sponsorlar ve reklam verenlerden ödeme kabul etmektedirler.

Tablo 1. "Temel özellikler ücretsiz" olan iş modelinde ödeme istenenler ve ödeme yapma gerekçeleri

\begin{tabular}{|c|c|c|c|c|}
\hline & \multicolumn{4}{|c|}{ Niçin Ödeme Yapıyor? } \\
\hline $\begin{array}{l}\text { Ödemeyi Yapan } \\
\text { Kim? }\end{array}$ & Kurs içeriğine & Veri ve analiz & $\begin{array}{l}\text { Platform } \\
\text { etkinliği }\end{array}$ & $\begin{array}{l}\text { Tamamlayıc1 } \\
\text { hizmetler }\end{array}$ \\
\hline Kullanıcılar & $\begin{array}{l}\text { Ders ücreti, } \\
\text { Reklamsız içeriğe } \\
\text { erişim, }\end{array}$ & Durum tespiti & Akran yardımı & $\begin{array}{l}\text { Sertifika } \\
\text { Özel ders } \\
\text { Grup } \\
\text { öğrenmesi }\end{array}$ \\
\hline Kamu kurumu & Devlet teşvikleri & & & \\
\hline İş veren & $\begin{array}{l}\text { Özel kurslar } \\
\text { Sürekli eğitim }\end{array}$ & $\begin{array}{l}\text { Çalışan } \\
\text { araştırma ve işe } \\
\text { alma, } \\
\text { Analiz, }\end{array}$ & & Sertifika \\
\hline $\begin{array}{l}\text { Sponsorlar / Reklam } \\
\text { verenler }\end{array}$ & Sponsorlu kurslar & & $\begin{array}{l}\text { Probleme } \\
\text { sponsor olarak } \\
\text { öğrenme }\end{array}$ & $\begin{array}{l}\text { Uzmanlara } \\
\text { erişim, }\end{array}$ \\
\hline
\end{tabular}

Kaynak: Dellarocas ve Van Alstyne, (2013, s. 26)'tan uyarlanmıştır.

Kullanıcılardan kurs içeriklerinin bir kısmı için ücret istenebilir. $\mathrm{Bu}$ iş modelinde işletme temel eğitim içeriklerini ücretsiz kullandırırken ek hizmetler için kullanıcılardan ücret isteyebilmektedir. Örneğin video içerikleri ücretsiz iken testler ücretli olabilmektedir. İkinci türü ise zaman kısıtlaması konulabilmektedir. Bu yöntemde kullanıcılar günde yarım saat ücretsiz oyun oynarken daha uzun süre oynamak için ücret ödemesi gerekmektedir. Üçüncü türü ise yapılan hata kısıtlamasıdır. Bunda günlük yapılacak hata sayısı belirlidir. Bunun üzerinde hata yapılmasına izin verilmez. Örneğin 5 hata hakkı verilmişse 5 hata sonunda günlük kullanım sonlanır. Yapılan doğrularla hata hakkını artıran versiyonlar da bulunmaktadır. Ayrıca bir sonraki bölüme ya da seviyeye geçmek için toplanacak puan kısıtlaması olan versiyonları da 
bulunmaktadır. Dördüncü kısıtlama türü ise etkileşim kısıtlamasıdır. Kullanıcının diğer kullanıcılarla etkileşim kurması, sorduğu sorulara cevap alması konusundaki kısıtlamaları içerir.

Üst seviyelere çıkabilmek için can, altın, madalya gibi oyun bileşeninin satın alındığı durumlarda oyunu tasarlayanlar, oyunda fark edilemeyen sinırlar koyarak bunlara sahip olmadan üst seviyelere çıkmayı engelleyebilmektedirler. Bu oyun geliştiricisi için çoğunlukla sabit ücretli oyun satışından daha yüksek gelirli olabilmektedir. Çünkü üst seviyelere her geçmek istediğinde kişi yeni bileşen satın almaktadır ve bunlar genellikle küçük miktarlar şeklinde olduğundan ödeme yapılırken çok önemli değilmiş gibi görünmekle beraber toplamda oldukça fazla olabilmektedir. Ücretsiz versiyonda oyunun erken aşamalarında ilerleme mümkün olmaması durumunda bu kişiler oyun oynamayı hemen bırakma eğiliminde iken, tüm seviyelere çıkmanın mümkün olduğu durumda ise ücretli versiyona geçmek için gerekçeleri kalmayacaktır. $\mathrm{Bu}$ nedenle oyun geliştiriciler sanal ürünlerden elde edecekleri gelirler ile reklam gelirlerinden elde edecekleri gelirleri dengeleyerek her bir ücret ve reklam izleme sonrası oyunda ne oranda ilerlenebileceğini hesaplamaları gerekir.

Kullanıcılardan ödeme yapmaları istenen bir diğer durum ise reklamsız içeriğe erişim içindir. İşletme reklam verenlerin reklamlarının gösterimini yapmak suretiyle gelir elde etmektedir. Ancak oyun içerisindeki reklamlar kullanıcılar açısından genelde rahatsızlık kaynağıdır. Çünkü reklamlar kullanıcıların çalışma sürelerinin verimliliğini düşürmektedir. Özellikle işletmenin uygun bir reklam kabul politikası yoksa kullanıcılara uygun olmayan reklamlar gösterilmektedir. Bu reklamlarda yetişkinler için olan ürün ve hizmetlerin tanıtımı olabileceği gibi, kullanıcılara uygun olmayan sosyal mecra reklamları veya şiddet içeriği de olabilmektedir. Reklamlarla ilgili ciddi bir endişe de kullanıcıların kimlik bilgilerinin veya kredi kartı bilgilerinin çalınmasıdır. Ayrıca kimi işletmeler gelirlerini artırabilmek için kullanıcıları bunaltabilecek kadar çok reklam alabilmektedirler. Geliştiriciler kullanıcılara reklamsız içerikleri ücret karşıllı̆ı vermektedir. Bu durumda işletme kaybedeceği reklam gelirini kullanıcılardan tahsil edeceğinden herhangi bir gelir kaybına uğramamaktadır. Nitekim kullanıcılar reklamlardan ve onların getirdiği risklerden kurtulacağ 1 gibi oyunu da daha güven içerisinde oynayabilecektir.

İşletmeler kullanıcıların eğitim almak istedikleri konuyla ilgili seviyelerini tespit etmek için de ücret isteyebilmektedir. Kullanıcılar hangi durumda olduklarını görebilmeleri ve daha verimli öğrenme ortamı oluşturabilmesi için detaylı raporlara erişebilmek için ücret ödemesi gerekir.

Öğrenme platformlarında akran yardımı olanağı olabilmektedir. Burada kullanıcılar karşılaştıkları sorunları birbirlerinin yardımı ile çözmeye çalışmaktadırlar. Bu durumda ücretli versiyonu kullanan kullanıcıların yardım istekleri daha üst sıralarda yer alır ve onun sorununu çözen üyelere fazladan ödüller verilir. Böylece ücretli üyeler daha çok ve hızlı akran yardımından yararlanabilirler.

Kullanıcılara ücretli versiyonda özel ders, danışmanlık ve eğitmenlere erişim gibi ek hizmetler sunulabilmektedir. Böylece kullanıcılar sistem içerisinde takıldığ 1 noktalarda eğitmenlere sorular sorabilmekte, ne yapması gerektiği ile ilgili geri dönüş alabilmektedir. Kullanıcılardan ücret istenebilen bir diğer özellik ise "grup öğrenmesidir". Kullanıcılar sanal gruplar oluşturarak birbirleriyle etkileşim kurmaktadırlar.

Eğitim amaçlı oyun üreticileri devlet teşviklerinden de yararlanabilirler. Teşviklerin biçimi ülkelere göre çeşitlilik göstermektedir. İşletmenin kuruluşunda verilen teşvikler, proje bazında verilen teşvikler, belirli bir içeriğin üretilmesi için verilen teşvikler ya da kullanıcı sayısına göre verilen teşvikler olabilmektedir. Devlet teşvikleri özellikle sermaye birikiminin az olduğu ülkelerde projelerin hayata geçirilebilmesi açısından hayati öneme sahiptir. Diğer durumlarda ise sektör oyuncularının yönlendirilmesi ve ülkenin eğitim politikası ile uyumlulaştırılması açısından önem arz etmektedir. 
Geliştirilen eğitim içerikli oyunları işverenler çalışanlarının gelişimine katkı sağlaması için kullanabilmektedirler. Böylelikle çalışanlara verilen eğitimler daha eğlenceli hale getirilmektedir. İşverenler çalışanları için özel kurslar yanından onların yaşam boyu öğrenmesini desteklemektedirler. İş verenler çalışanları için gerekli olan sertifikaların alınması için ücret ödeyebilirler.

İşletmelerin eğitim içerikli oyunlar için ödeme yapmasının bir diğer gerekçesi ise işletmesi için uygun çalışanları araştırma ve işe almadır. Eğitim içerikli oyunlar sayesinde işletmeler belirli bir konuya ilgi gösteren geniş bir aday havuzuna erişim sağlayabilmektedirler. Böylece iş veren aradığı nitelikteki adaylara yarışmalar düzenleyerek ulaşabilir ve onları işe alabilir.

Reklam gelirli iş modellerinde temel olarak eğitim materyali ücretsiz veya düşük fiyatla satılmaktadır. Bu modellerde gelir ürünün içerisinde gösterilen reklamlardan elde edilir. Reklamlar oyun aralarında gösterildiği gibi oyuna eklemlenmiş olarak da gelebilir. Burada çocuklara yönelik reklamlar özellikle tartışmalı bir konudur. Çocuklara yönelik zararlı olabilecek meşrubat ve abur cuburlara yönelik hassasiyet oldukça yoğundur (Burns ve Bush, 2015, s. 31). Özellikle sponsorlu veya reklam içeren eğitim materyalleri konusunda dikkatli olmak da fayda görülmektedir. Çünkü bunlarda oyundaki karakter tüketim normlarını belirleyebildiğinden çocuklar ders konularının yanı sıra tüketim normlarını da öğrenebilirler. Özellikle sağlıksız ürünler hususunda çocuklara gösterişçi tüketim ve materyalisttik değerlerin aşılanabileceği dikkate alınmalıdır. Ayrıca çocuk oyunlarında cinsel ve şiddet içeriği olan reklamları ayıklamayan yayıncıların olması, bu reklamlara tıklanarak cihaz bilgilerinin alınması, mikrofona, kameraya erişim izinleri çocukları yetişkinlerin olduğu sosyal medyaya yönlendirmek gibi pek çok sakıncayı içerdiklerini de söyleyebilmek mümkündür.

Temel özelliklerin ücretsiz olduğu modelde çoğunlukla işletmeler gelir elde edebilmek için içeriğin geliştirilmesi aşamasında sponsorlardan yararlanmaktadırlar. Burada sponsor olan işletmenin ürün ve hizmetlerini yaygınlaştırma, nasıl kullanılacağını öğretme, imaj oluşturma hedeflenmektedir. Örneğin sponsorlu kurslarda, bir müze sanat eseri yorumlama ile ilgili bir eğitime; süt markası süt içince nasıl sağlıklı büyüyebileceğine ilişkin bir oyuna; bir otomobil işletmesi yeni tür otomobillerinin sürüş özelliklerini; bir meşrubat işletmesi ise oyundaki güçlükleri aşmada nasıl yardım edeceğini gösterebilir. Eğitim içeriği geliştirildikten sonra da sponsor alımı yapılabilmektedir ancak bu durumda oyun tamamen sponsor için geliştirilmez, yalnızca oyun içerisine ürün yerleştirmeler yapılabilir. Böyle bir durumda oyuna eklemlenmiş olanlarda oyundaki karakterin giysisi sponsor işletme logosunu içerebilir, karakter sponsor markanın meşrubatını içince güçlenebilir veya oyunun geçtiği mekân sponsorun mağazasının içi olabilir. Bazı zamanlarda sponsorlar oyunculara belirli konudaki bir problemlerini vererek onlardan çözüm geliştirmelerini bekleyebilirler. Bu durumda sponsor sorunun çözümü için harekete geçirmek için bir yarışma düzenleyebilir. Aynı şekilde sponsorlar belirli konuda uzmanlığg olan kişilere erişim sağlayabilmek için de belirli bir ücret ödeyebilirler.

Sponsorun olmadığı son durumda ise sadece reklam alınır, reklam veren oyun içeriğinde yer almaz sadece belirli aralıklarla onun reklamı gösterilir ve reklam bedeli alınır. Reklamı sonuna kadar izleyen ya da tüm anket sorularına cevap veren kişilere oyun içerisinde puan ya da sanal para teklif edilmektedir. Böylece işletme kullanıcılarını reklamı sonuna kadar izlemeye motive ettiği oranda gelirlerini artırabilmektedir.

Ancak bu durumda reklam verenin hedef kitlesi ile oyunun hedef kitlesinin uyumlu olması gerekir. $\mathrm{Bu}$ uyumun olmaması durumunda her iki işletmenin de zararına durumlar oluşabilecektir. Öncelikle kullanıcılar oyun oynamayı bırakabilirler veya uygun olmayan reklamlar dolayısıyla velileri tarafindan oynamaları engellenebilir. $\mathrm{Bu}$ sebeple oyun geliştiricilerin hedef kitlelerine uygun olmayan reklamları kabul etmeleri uzun dönemde zararlı sonuçlar verecektir. 


\subsubsection{Kitle Fonlamast}

Eğitim amaçlı oyunların geliştirilmesi esnasında kullanılabilecek bir diğer yöntem ise kitle fonlamasıdır. Kitle fonlaması (crowdfunding), bağışçılardan ve yatırımcılardan internet üzerinden para toplayabilmenin etkin bir yoludur (The World Bank, 2013, s. 8). Kitle fonlamasında geliştirilecek proje için gerekli kaynak ona destek olmak isteyen çok sayıdaki kişinin görece küçük katkıları sonucunda ortaya çıkmaktadır.

Kitle fonlaması yapılan projelerin önemli avantajları vardır. Öncelikle projenin yapılması yeterli desteğin bulunmasına bağlıdır. Bunun için yeterli sayıda kişinin projeyi beğenmesi ve projeye destek olacak kadar iyi bulmas1 gerekmektedir. Böylece projenin toplumdan kabul görüp görmeyeceği ile ilgili bir ön araştırma yapılmış olur. Ayrıca projeyi hazırlayanın bir işletme olması ya da projeyi yapabilecek kadar sermayesinin olması da gerekmemektedir. Projeyi yapabilecek organizasyon becerisinin olması yeterlidir. Böylece proje yapacak kişilerin sermaye sahibi olması ve sermeye sahibi işletmeleri ikna etmelerine gerek kalmaksızın projelerini yapabilmelerine olanak sağlanmaktadır. Projenin toplumun daha geniş kesimlerinden ortaya çıkmasının yolu açılmaktadır. Kitle fonlamasındaki projelerin özelliklerini proje sahibi belirlediği, konu ve projenin hazırlanış biçiminde daha esnek olunabildiği için kamu projelerine göre daha yaratıcı projeler ortaya çıkabilmektedir. Kitle fonlaması ile proje hazırlayanlar, büyük işletmelerin kapsamlı yatırım planları yapması ve var olan gelirlerini koruma gibi güdüleri olmadığı için daha radikal yenilikler yapma konusunda istekli olacaklardır.

Kitle fonlaması gelir modeli genellikle projenin hayata geçirilmesi esnasında daha uygun bir model olarak görülmektedir. Projenin ileriki zamanlarında sürekli gelir olarak düşünülmemelidir. $\mathrm{Bu}$ durumda kitle fonlaması asıl masrafın geliştirilme esnasında yapıldığı, sonrasında daha az kaynağın gerektiği projeler için daha uygun bir model olduğu söylenebilir.

\subsubsection{Bağıs}

$\mathrm{Bu}$ gelir modelinde tamamen bağışlara dayalı olan eğitim amaçlı oyunlar yer almaktadır. Bu modelde ticari bir işletmeden ziyade daha çok vakıf olarak örgütlenme söz konusudur. Bunlar öğrenci, eğitmen ve eğitim kurumları için tamamen bedava hizmet sunarlar. İçerik üretmek ve bu içeriklerin hedef kitleye ulaştırılması için bağışları kabul ederler. Bu yapılanma biçiminde ülkenin en başarılı eğitimcilerinin gönüllü desteğini alabilme imkânı vardır. Böylece içerik üretim maliyetleri azalır ve kullanıcılara ücretsiz nitelikli eğitim materyalleri sağlanır. Bu yöntemde bağışların sürekliliğini sağlamak ve birkaç büyük bağışçının özel isteklerine bağımlı olmadan uzun süre nitelikli materyal üretmek en zorlu kısmıdır.

\section{Sonuç ve Öneriler}

İnsanlar çocukluktan itibaren hayatla ilgili pek çok şeyi oyunlar sayesinde öğrenmektedirler. Eğitim amaçlı oyunlar da insanlardaki oyun oynama konusundaki eğilimlerinden yararlanmaktadır. Burada amaç öğrenmenin gerçekleşmesidir. Eğlence ise öğrenmeyi sağlayan araç olarak nitelendirilmektedir. Bu sebeple bu tür oyunların temelinde eğitim ve öğretim bulunmaktadır. Eğlence ise onun çevresini sarmakta, kişilerin eğlenmeleri ve motive olmalarını sağlamaktadır. Bu sayede öğrenme kolaylaşmaktadır. Ancak bu süreç iyi tasarlanmalıdır. Eğitim ve eğlence dengesi iyi sağlanamazsa sistemin başarılı olabilmesi beklenemez.

Geliştiriciler tasarlayacakları oyunun iş modelini oluştururken öncelikli olarak hedef kitleyi tanımlamalıdırlar. Hedef kitlenin doğru tespit edilmesi onların ihtiyaçlarının ne olduğu, onlara nasıl ulaşılabileceğine ve gelirin nasıl sağlanabileceği ile ilgili cevapların verilmesini kolaylaştıracaktır. Hedef kitle pazarın tamamı ya da onun bir kısmı olabilir. Hedef kitlenin yanlış belirlenmesi işin başarısız olması, aşırı rekabetin içine girilmesi ya da küçük bir alana hapsolmas1 anlamına gelmektedir. 
İş modeli tasarlanırken ikinci aşama değer önerisinin belirlenmesidir. Bu aşamada hedef kitlenin "neden bizi tercih edecekleri" sorusunun net olarak cevaplanması gerekir. İyi bir değer önerisi müşterilerin satın alma tercihlerini belirleyen bir durumla ilişkili olmalı, rakipler tarafından sahiplenilmemiş olmalı, işletmenin sürdürülebilirliği olan üstünlüğüne dayanmalıdır.

İş modeli tasarımının üçüncü aşamasında dağıtım kanalının belirlenmesi gelmektedir. Eğitim amaçlı oyunu kullanmak isteyenlerin oyuna nerelerden erişebileceklerinin tespiti önemli bir husustur. Temelde seçenekler, işletim sistemi üreticilerinin sanal mağazaları (Microsoft Store, Google Play, App Store), oyun konsolu üreticilerinin sanal mağazaları (Play Station Store, Xbox Live), dağıtım şirketlerinin sanal mağazaları, devletlerin dijital öğrenme platformları, teknoloji perakendecileri, geliştiricinin kendi sitesi ve diğer sanal mağazalardır. Bu seçeneklerden hangisinin ya da hangilerini kullanılacağı hedef kitlenin kullanım alışkanlıkları, rakiplerin kanal tercihleri ve her bir kanala erişim zorluğu ve maliyete bağlı olarak değişkenlik gösterebilecektir.

Geliştiricilerin masraflarını karşılaması ve kâr elde edebilmesi için farklı gelir modelleri bulunmaktadır. Geliştiriciler ücretli gelir modelinde oyunlarını satarak gelir elde etmektedirler. Temel özellikler ücretsiz iş modelinde temel özellikleri kullanan kişilerden herhangi bir ücret alınmamaktadır. Ancak ek özellikler isteyen az sayıda kişiden gelir elde edilmesi mümkündür. Ayrıca kamu kurumlarından, iş verenlerden, sponsorlardan ve reklam verenlerden de gelir elde etme olanakları bulunmaktadır. Görüldüğü gibi temel özelliklerin ücretsiz olduğu iş modelinde müşterilerin çok büyük bir oranını ücret ödemeye ikna etmek mümkün olmasa dahi işletme pek çok farklı gruptan gelir elde edebilme olanağına sahiptir. Bu gelir modelinin sıklıkla kullanılması geliştiricilerin geliri çeşitlendirme isteklerinden kaynaklanmaktadır. Bu gelir modelinin bir diğer avantajı çok sayıda kullanıcının denemek için kullanmasını sağlamaktır. Oyunun akranlar arasında bilinirliği artmaktadır. Ücretsiz versiyonu kullanan kişiler ücretli kullanacak kişileri davet edebilmektedirler. Hatta pek çok örnekte arkadaşları davet etmek teşvik edilmektedir. Ücretsiz versiyonu kullanan kişiler ücretli versiyonu kullanan kişileri destekleyecek şekilde teşvik edebilirler. Böylece ücretsiz versiyonu kullananların çok olması ücretli versiyonu kullanan kişilerin aldıkları hizmetin kalitesini artırabilecektir. Ücretsiz versiyonu kullanan kişiler işletme için her zaman kârsız değillerdir. Bu kişiler iyi reklam alabilen işletmeler için kârlı dahi olabilmektedirler. Bu durumda işletme ücretli ve ücretsiz versiyonu kullananlar arasında denge kurarak gelirlerini ciddi biçimde artırabilir. Burada işletmeler ücretsiz versiyonu kullanan kişileri taciz etmeden, onları reklamla bunaltmadan ve gayretleri sonucunda oyunda ilerlemelerini sağlayarak sistemde kalmalarını sağlamalı, ancak ücretli versiyonla daha fazla eğlence ve öğrenme imkânı sağlayarak onları satın almaya teşvik etmelidir. Geliştiricinin ücretli versiyona geçiş konusundaki 1srarı ücretli versiyonları satın almaya yönlendirmek yerine kullanıcının oyun oynamayı bırakmasıyla da sonuçlanabileceği göz önünde bulundurulmalıdır. Buradaki hassas dengeyi sağlayabilmek son derece önemli olacaktır. Bir diğer gelir modeli genellikle oyunun geliştirilme öncesinde çok sayıda kişiden para toplanarak projenin gerçekleştirilmesini sağlayan kitle fonlamasıdır. Bu yöntem finansal açıdan yetersiz olan kişilerin büyük işletmeler ve devlet desteğine ihtiyaç duymaksızın oyun geliştirebilmesini olanaklı kılmaktadır. Sonuncu gelir modeli olarak ise bağışlar sayılabilir. Geliştiricinin girişimini bir vakıfa çevirmesi ve sürekli bağış alabilmesini gerekir.

Oyun geliştiricisinin üç gruptan en az birinden ödemeyi alabilmesi gerekir. İlk ve en olası grup hedef kitlenin kendisidir. Bu durumda eğitim amaçlı oyunu ücret karşıllğında satması veya oyun içi satışlar yapması gerekir. İkinci olarak kullanıcılara ulaşmak isteyen reklam verenlerdir. Hedef kitle reklam verenler açısından cazipse geliştiricinin reklam gelirleri yeterli olacaktır. Üçüncüsü ise hedef kitlenin eğitimini üstlenmek isteyen sponsorların olması durumunda geliştirici ödemeyi sponsorlardan alırlar. Özellikle kamu kurumlarının, belirli amaçlarla kurulmuş vakıfların ve ürettikleri ürünlerin yaygınlaşmasını isteyen üretici birliklerinden gelir elde edilebilir. Burada geliştiriciler gelirlerini bu gruplardan birinden elde edebilecekleri gibi iki ya da üçünden de elde edebilirler. Geliştirici her pazar bölümü için bu üç 
gruptan ne ölçüde gelir elde edebileceğini hesaplamalıdır. Sadece kullanıcıların ödemelerine göre yapılan analiz eksik olacaktır.

Eğitim amaçlı oyunların iş modellerini belirlemeye yönelik olan bu çalışmanın önemli kısıtları olduğu gözden kaçırılmamalıdır. Çalışmada birincil veri toplanmamıştır. Bundan sonraki çalışmalarda girişimcilerden, kullanıcılardan, eğitmenlerden ve eğitim kurumu yöneticilerinden birincil veri toplamaları önerilir. Böylece farklı iş modeline sahip oyunların ticari başarıları, süreklilikleri, ulaşılan kullanıcı sayısı, eğitime faydaları gibi konular daha detaylı olarak incelenebilir. Eğitim amaçlı oyunların başarılarını etkileyen unsurların tespit edilmesi ile daha başarılı ürünler geliştirilerek eğitimin niteliğinin artmasına katkıda bulunulabilir ve bu alana yatırım yapan kişi ve kurumların kaynaklarının israf olması önlenebilir. Bu çalışmalar işletme ve eğitim bilimleri alanındaki araştırmacıların katıldığ disiplinler arası özellikte olması hiç kuşkusuz daha detaylı bilgilerin ortaya çıkmasını sağlayacaktır. Konu eğitim olduğunda geliştiricilerin etik davranışları daha önemli olacaktır. Özellikle hedef kitlesi çocuklar olan eğitim amaçlı oyunlarda geliştiricilerin oyuna sponsorların isteği ile yerleştirdikleri unsurların çocukları nasıl yönlendirdiklerinin belirlenmesi önemli olacaktır. Eğitim amaçlı oyunların iş modellerinin anlaşılması eğitimcilerin derslerinde uygulayabilecekleri oyunların niteliğinin artmasında, yetenekli insanların bu alanlarda istihdam edilebilmesinde, projesi olan kişilere verilen destekler sonunda başarılı oyunların ortaya çıkmasında etkili olabilecektir. Tüm eğitim sistemi açısından değerlendirildiğinde toplumun daha nitelikli eğitime ulaşımını olanaklı kılacak iş yapma biçimleri ortaya çıkacaktır. Böylece toplumlar için en önemli kaynak olan insan kaynă̆ının niteliğinin gelişmesine katk1 sunabilecektir.

\section{Kaynakça}

Adkins, S.S. (2017). 2017-2022 Global game-based learning market, http://seriousplayconf.com/wp-content/uploads/2017/07/Metaari_2017-2022_Global_Gamebased_Learning_Market_Executive_Overview.pdf (Erişim Tarihi: 23.05.2018)

Admiraal, W., Huizenga, J., Akkerman, S., ve Ten Dam, G. (2011). The concept of flow in collaborative game-based learning. Computers in Human Behavior, 27, 1185-1194. https://doi.org/10.1016/j.chb.2010.12.013

Altuntaş, B., ve Karaarslan, M. (2016). Türkiye'deki seçilmiş pazarlama vakalarının oyunlaştırma kavramı çerçevesinde incelenmesi. Mehmet Akif Ersoy Üniversitesi Sosyal Bilimler Enstitüsü Dergisi, 8 (17), 433-447. Retrieved from https://dergipark.org.tr/tr/pub/makusobed/issue/45268/567041

Altuntaş, B., ve Karaarslan, M. H. (2017). Kullanıcıların mobil oyun tercihinde etkili olan faktör düzeylerinin öneminin belirlenmesi. International Journal of Economic and Administrative Studies, (19):277-298.

AMA, (2020). American marketing association "AMA Dictionary" https://marketingdictionary.org Erişim Tarihi: 20.10.2020

Barneto, P., ve Ouvrard, S. (2015). Is The Firm's business model related to segment reporting? Research in International Business and Finance, 35, 122-137. doi:10.1016/j.ribaf.2015.06.001

Basalla, G. (1996). Teknolojinin Evrimi, (C. Soydemir Çev.). Ankara: TÜBİTAK Yayınevi.

Başak, M. H., ve Ayvacı, H. Ş. (2017). Teknoloji entegrasyonunun eğitim alanında uygulanmasına yönelik bir karşılaştırma: Türkiye-Güney Kore örneği. Education and Science, 42(190), 465-492. doi:10.15390/EB.2017.6710 
Bolat, İ. Y., Şimşek, Ö., ve Ülker, Ü. (2017). Oyunlaştırılmış çevrimiçi sınıf yanıtlama sisteminin akademik başarıya etkisi ve sisteme yönelik görüşler. Abant İzzet Baysal Üniversitesi Eğitim Fakültesi Dergisi, 17(4), 1741-1761.

Bunchball (2016). What is Gamification? http://www.bunchball.com/gamification (Erişim Tarihi: 23.05.2018)

Burns, A. C., ve Bush, R. F. (2015). Pazarlama araştırması., F. Demirci Orel, (Çeviri Editörü) Ankara: Nobel Yayınları.

Cagnina, M. R., ve Poian, M. (2009). Beyond e-business models: the road to virtual worlds. Electronic Commerce Research, 9, 49-75. Doi:10.1007/s10660-009-9027-3

Chesbrough, H. W., ve Rosenbloom, R. S. (2002). The role of the business model in capturing value from innovation: Evidence from Xerox Corporation's technology spinoff companies. Industrial and Corporate Change, 11: 533-534.

Collinsdictionary, (2020). https://www.collinsdictionary.com/dictionary/english/revenue-stream Erişim Tarihi: 20.10.2020

Çelik, S., Karakuş, T., Kurşun, E., Göktaş, Y., ve Özben, M. (2017). Pedagogical problems encountered by teachers and students in technology-enhanced learning environments: A Case of FATIH Project. Journal of Education and Future, (12), 67-83.

Dellarocas, C., ve Van Alstyne, M. (2013). Money models for MOOCs. Communications of the $A C M, 56(8), 25-28$.

Georgieva, G., Arnab, S., Romero, M., ve de Freitas, S. (2015). Transposing freemium business model from casual games to serious games. Entertainment Computing, 9, 29-41.

Güneş, F. (2015). Oyunla öğrenme yaklaşımı/game-based learning approach. Turkish Studies, $10,773-786$

Karataş, E. (2014). Eğitimde oyunlaştırma: araştırma eğilimleri. Ahi Evran Üniversitesi Kırşehir Eğitim Fakültesi Dergisi, 15(2), 315-333.

Laamarti, F., Eid, M., ve Saddik, A. E. (2014). An overview of serious games. International Journal of Computer Games Technology, 2014, 11, 1-15.

Lasry, N. (2008). Clickers or flashcards: Is there really a difference?. The Physics Teacher, 46(4), 242-244.

Magretta, J. 2002. Why business models matter. Harvard Business Review, 80(5): 86-92.

Morris, M., Schindehutte, M., ve Allen, J. (2005). The entrepreneur's business model: toward a unified perspective. Journal of Business Research, 58(6), 726-735.

Osterwalder, A., ve Pigneur, Y. (2016). İs Modeli Üretimi, İstanbul: Optimist Yayınevi.

Patterson, B., Kilpatrick, J., ve Woebkenberg, E. (2010). Evidence for teaching practice: The impact of clickers in a large classroom environment. Nurse Education Today, 30, 603-607. https://doi.org/10.1016/j.nedt.2009.12.008

The World Bank (2013). Crowdfunding's Potential for the Developing World, Washington.

Werbach, K., ve Hunter, D. (2012). For the win: How game thinking can revolutionize your business. Wharton Digital Press.

Wouters, P., Van Nimwegen, C., Van Oostendorp, H., ve Van Der Spek, E. D. (2013). A metaanalysis of the cognitive and motivational effects of serious games. Journal of Educational Psychology, 105(2), 249. Doi:10.1037/a0031311 
Yapıc1, Ş. (2006). Bir eğitim aracı olarak televizyon ve etkileri. Bilim, Eğitim ve Düşünce Dergisi, 6, (2) Link: http://www.universite-toplum.org/text.php3?id=272 Erişim Tarihi: 27.02. 2018.

Zott, C., Amit, R., ve Massa, L. (2011). The business model: recent developments and future research. Journal of management, 37(4), 1019-1042.

\section{ETİK ve BIILIMSEL İLKELER SORUMLULUK BEYANI}

$\mathrm{Bu}$ çalışmanın tüm hazırlanma süreçlerinde etik kurallara ve bilimsel atıf gösterme ilkelerine riayet edildiğini yazar(lar) beyan eder. Aksi bir durumun tespiti halinde Afyon Kocatepe Üniversitesi Sosyal Bilimler Dergisi'nin hiçbir sorumluluğu olmayıp, tüm sorumluluk makale yazarlarına aittir. 